\title{
Hubungan Inisiasi Menyusu Dini (IMD), Mobilisasi Dini dan Senam Nifas dengan Involusi Uteri
}

\author{
Ayundya Prameswary ${ }^{1}$, Fazar Kumaladewi ${ }^{2}$ \\ ${ }^{1,2}$ Program Studi Sarjana Terapan Sekolah Tinggi Ilmu Kesehatan Indonesia Maju \\ Jln. Harapan nomor 50, Lenteng Agung-Jakarta Selatan 12610 \\ Telp: (021) 78894045, Email : ${ }^{1}$ ayundyaprameswary@gmail.com; ${ }^{2}$ fazarks@gmail.com
}

\begin{abstract}
Abstrak
Masa nifas adalah masa setelah persalinan, kelahiran bayi, plasenta, serta selaput nya. Saat masa nifas diperlukan tindakan untuk memulihkan kembali organ kandungan seperti sebelum hamil dengan waku kurang lebih 6 minggu. Penelitian ini dilakukan untuk mengetahui Hubungan Inisiasi Menyusui Dini (IMD), Mobilisasi Dini, dan Senam Nifas dengan Involusi Uteri di RSUD ABD AZIZ Kota Singkawang, Kalbar. Penelitian ini dilakukan pada bulan Desember 2017 di RSUD Abd. Aziz Kota Singkawang, Jenis penelitian ini adalah penelitian kuantitatif dengan metode cross sectional. Populasi target dalam penelitian ini adalah seluruh ibu nifas di RSUD Dr Abd. Aziz Kota Singkawang sebanyak 30 orang. Sampel diambil dengan metode total sampling. Hasil uji statistik didapatkan nilai $\mathrm{P}$ value $=0,584$ berarti $\mathrm{p}$ value $>\propto(0,05)$, sehingga dapat disimpulkan tidak ada hubungan inisisasi menyusu dini dengan involusi uteri di RSUD ABD AZIZ Kota Singkawang, Kalbar tahun 2017. Hasil uji statistik didapatkan nilai $P$ value $=0,045$ berarti $p$ value $<\propto(0,05)$, sehingga dapat disimpulkan ada hubungan mobilisasi dengan involusi uteri di RSUD ABD AZIZ Kota Singkawang, Kalbar tahun 2017. Hasil uji statistik didapatkan nilai $P$ value $=0,030$ berarti $p$ value $<\propto(0,05)$, sehingga dapat disimpulkan ada hubungan senam nifas dengan involusi uteri di RSUD ABD AZIZ Kota Singkawang, Kalbar tahun 2017. Saran Kepada Tenaga Kesehatan selaku Penyedia Pelayanan Kesehatan terutama Bidan memberikan edukasi kepada ibu postpartum tentang bagaimana mencegah terjadinya involusi uteri.
\end{abstract}

Kata Kunci : Inisiasi Menyusu Dini (IMD), Mobilisasi Dini, Senam Nifas

\begin{abstract}
Puerperal period is the period after childbirth, childbirth, placenta, and membrane. During childbirth is necessary action to restore the pregnant organs such as before pregnancy with waku approximately 6 weeks. This study was conducted to determine the relationship of Early Breastfeeding Initiation (IMD), Early Mobilization, and Gymnastics Gymnastics with Invitation Uteri in RSUD ABD AZIZ Singkawang, West Kalimantan. This research was conducted in December 2017 at RSUD Abd. Aziz Kota Singkawang, This research type is quantitative research with cross sectional method. The target population in this study were all postpartum mothers in RSUD Dr Abd. Aziz City Singkawang as many as 30 people. Samples were taken by total sampling method. Result of statistic test got value $P$ value $=0,584$ mean $p$ value $>\alpha(0,05)$, so it can be concluded there is no relationship of initialization of early breastfeeding with uterine involution in RSUD ABD AZIZ Singkawang, West Kalimantan 2017. Statistical test results obtained value $P$ value $=0,045$ means $p$ value $<\alpha(0,05)$, so it can be concluded that there is a mobilization relationship with uterine involution in RSUD ABD AZIZ Singkawang, West Kalimantan 2017. The result of statistical test obtained $P$ value $=0,030$ means $p$ value $<\alpha(0,05)$, so it can be concluded that there is a puerperal gymnastics relationship with uterine involution in RSUD ABD AZIZ Singkawang, West Kalimantan 2017. Suggestions To Health Workers as Health Service Providers, especially Midwives provide education to postpartum mothers about how to prevent involution uteri .
\end{abstract}

Keywords : Early Breastfeeding Initiation (IMD), Early Mobilization, Nifas Gymnastics 


\section{Pendahuluan}

Masa nifas merupakan hal penting untuk diperhatikan guna menurunkan angka kematian ibu dan bayi di Indonesia. Menurut pakar kesehatan yang mempunyai pengalaman dalam menanggulangi angka kematian ibu dan bayi di beberapa negara, mereka memfokuskan pertolongan pada periode intrapartum dan ini memberikan bukti nyata dalam menyelamatkan lebih dari sepuluh ibu bersalin dan bayi baru lahir yang sering disertai dengan penyulit pada proses persalinan atau komplikasi yang mengancam jiwa. Tetapi tidak semua tindakan yang dilakukan cocok dan dapat memberikan dampak yang menguntungkan untuk diterapkan kembali pada negara lain. Oleh karena itu dengan adanya asuhan pada masa nifas ini diharapkan dapat menurunkan angka kematian dan kesakitanpada ibu dan bayi. Penatalaksanaan asuhan kebidanan yang menyeluruh dan teratur akan meningkatkan pelayanan asuhan kebidanan yang bermutu pada ibu di masa nifas dan pelayann juga ditujukan untuk memantau tanda-tanda bahaya nifas serta kemungkinan-kemungkinan tanda bahaya yang akan terjadi. ${ }^{1}$

Masa nifas adalah masa setelah persalinan, kelahiran bayi, plasenta, serta selaputnya. Saat masa nifas diperlukan tindakan untuk memulihkan kembali organ kandungan seperti sebelum hamil dengan waku kurang lebih 6 minggu. Dalam masa pemulihan ibu post partum sangat membutuhkan dukungan dari keluarganya karena dukungan dari keluarga sangat menentukan berhasil atau tidaknya proses pemulihan ibu pada masa nifas. Beberapa perubahan yang akan dialami oleh ibu post partum pada masa nifas biasanya berupa perubahan fisik dan perubahan psikis.

Pada perubahan fisik terdapat perubahan ligament-ligamen yang bersifat lembut dan kendor, otot-otot menjadi tegang, uterus ibu membesar, postur tubuh ibu biasanya berubah mengikuti perubahan berat badan ibu selama hamil. Biasanya pada saat hamil tubuh ibu akan mengalami kenaikan sekitar 10 - $15 \mathrm{~kg}$.

Bukan hanya pemerintah yang memiliki tanggung jawab untuk memberikan pelayanan yang baik kepada setiap ibu, masyarakat juga memiliki tanggung jawab yang sama agar setiap ibu mendapatkan akses pelayanan kesehatan yang berkualitas dan baik, dimulai dari ibu saat masa hamil, melahirkan ditolong oleh tenaga kesehatan yang terampil dan terlatih, serta perawatan pada masa nifas bagi ibu dan bayi, perawatan khusus dan rujukan jika terjadi komplikasi pada ibu dan bayi, dan akses untuk mendapatkan pelayanan keluarga berencana. Kemudian dalam upaya untuk mempercepat penurunan AKI harus dilakukan pencegahan dan penyuluhan kepada remaja. ${ }^{2}$

Involusi uterus adalah proses kembalinya uterus segera setelah bayi dan plasenta lahir ke kondisi seperti sebelum hamil dengan berat hanya mencapai sekitar 60 gram melalui proses alamiah beruba kontraksi otot-otot polos uterus dan retraksi serabut otot uterus yang terjadi secara terus menerus selama masa nifas. Apabila terjadi kegagalan involusi uterus maka akan menyebabkan sub involusi.

Gejala dari subinvolusi itu sendiri biasanya meliputi lochea menetap/merah segar, penurunan fundus uteri lambat, tonus uteri lembek, tidak ada perasaan mules pada ibu nifas akibatnya terjadi perdarahan. Perdarahan itu sendiri biasanya ditandai dengan keluar nya darah secara terus menerus melalui jalan lahir yang biasanya terjadi selama atau setelah kala III, biasanya jumlah darah yang keluar lebih dari $500 \mathrm{ml}$. Sampai saat ini perdarahan merupakan salah satu penyebab terbesar kematian ibu post partum dengan persentase 50-60\% disebabkan karena lemah atau tidak adanya kontraksi dari uterus. Biasanya perdarahan yang massif berasal dari tempat implantasi plasenta, robekan pada jalan lahir dan jaringan sekitarnya itu semua merupakan salah satu penyebab kematian ibu disamping perdarahan karena hamil ektopik dan abortus. Perdarahan yang menetes perlahan-lahan tetapi terus menerus juga berbahaya. ${ }^{3}$

Salah satu usaha yang dilakukan untuk mengembalikan perubahan-perubahan yang terjadi pada masa hamil, persalinan dengan melaksanakan senam nifas agar kembali seperti semula sebelum hamil. Manfaat senam nifas adalah memulihkan kembali kekuatan otot dasar panggul, mengencangkan otot-otot dinding perut dan perineum, membentuk sikap tubuh yang baik dan mencegah terjadinya komplikasi. Komplikasi yang dapat dicegah 
sedini mungkin dengan melaksanakan senam nifas adalah perdarahan post partum.

Saat melakukan senam nifas terjadi kontraksi otot-otot perut yang akan membatu proses involusi yang mulai setelah plasenta keluar segera setelah proses involusi. Pada masa nifas, alat-a;at genitalia interna maupun eskterna akan berangsur-angsur pulih kembali setelah keadaan sebelum hamil. Perubahanperubahan alat genitalia ini dalam keseluruhannya disebut involusi. ${ }^{4}$

Inisiasi menyusu dini (IMD) merupakan salah satu faktor yang mempengaruhi perubahan uterus pada ibu postpartum. Inisiasi menyusu dini atau permulaan menyusu dini adalah bayi mulai menyusu sendiri satu jam setelah lahir. Pengisapan puting payudara oleh bayi pada awal masa nifas memperkuat stimulasi pengeluaran oksitosin yang bermanfaat untuk merangsang kontraksi uterus pada ibu setelah melahirkan atau pada masa nifas. $^{5}$

Mobilisasi dini adalah (ambulasi dini / early ambulation) dapat mengurangi bendungan lochea dalam rahim, meningkatkan perdarahan sekitar alat kelamin, mempercepat pengembalian alat reproduksi ke keadaan semula. Mobilisasi dini sangat penting dalam mencegah trombofeblitis. Setelah persalinan normal jika gerakan nya tidak terhalang oleh pemasangan infus dan tanda-tanda vitalnya juga normal, biasanya juga ibu untuk mandi dan pergi ke kamar mandi dengan dibantu oleh salah satu keluarga atau sendiri pada 1 atau 2 jam setelah persalinan. ${ }^{6}$

Senam nifas merupakan salah satu cara untuk mengurangi berbagai masalah atau gangguan fisiologis maupun psikologis yang terjadi pada ibu postpartum. Hal ini karena senam nifas merupakan cara untuk mobilisasi dini yang sangat dianjurkan untuk ibu postpartum. Manfaat dari latihan ini hubungannya dengan pemulihan fisik pada ibu yang melakukannya yaitu mencegah diastasis rektus abdominis dan mengencangkan otot abdomen, sehingga angka prevalensi kejadian diastasis rectus abdominis dapat diturunkan. ${ }^{7}$

Berdasarkan studi pendahuluan di RSUD ABD AZIZ Kota Singkawang Tahun 2017 dari 10 ibu postpartum diketahui bahwa ada 4 orang ibu yang mengalami Involusi uteri tidak normal yaitu TFU berada lebih dari $6 \mathrm{~cm}$ di pinggir atas Sympisis. 3 ibu postpartum tidak melakukan IMD, 6 ibu postpartum yang tidak melakukan mobilisasi dini dan ada 7 orang ibu tidak melakukan senam nifas.

Tujuan penelitian ini Untuk mengetahui apakah ada Hubungan Inisiasi Menyusu Dini (IMD), Mobilisasi Dini, dan Senam Nifas dengan Involusi Uteri antara di RSUD ABD AZIZ Kota Singkawang, Kalbar tahun 2017.

\section{Metode}

Penelitian ini adalah penelitian survey yang bersifat deskriptip kuantitatif, deskriptif kuantitatif adalah penelitian yang dilakukan untuk mengetahui nilai dari suatu variabel, dalam hal ini variabel mandiri, baik satu variabel maupun lebih tanpa membuat perbandingan atau menghubungkan dengan variabel lain. Dengan melakukan pendekatan secara cross sectional (pendekatan silang), yaitu suatu penelitian untuk mempelajari dinamika korelasi antara faktor-faktor resiko dengan efek, dengan cara pendekatan, observasi atau pengumpulan data sekaligus pada waktu yang bersamaan. ${ }^{8}$ Alasan pemilihan desain studi cross sectional karena mudah dilakukan, lebih ekonomis, dan hasilnya dapat diperoleh dengan cepat.

Penelitian dilakukan terhadap hubungan IMD (inisiasi menyusu dini), mobilisasi dini, dan senam nifas dengan involusi uteri di RSUD Abd. Aziz Kota Singkawang Tahun 2017.

Instrumen dalam penelitian adalah alat yang digunakan untuk mengumpulkan data. Alat ukur yang digunakan untuk mengukur hubungan inisiasi menyusu dini, mobiliasi dini dansenam nifas terhadap involusi uteri di RSUD Dr. Abd Aziz Kota Singkawang Tahun 2017 adalah Checklist. Checklist digunakan sebagai alat untuk mengukur variabel dependen Involusi Uteri dan variabel independen inisiasi menyusu dini (IMD), mobilisasi dini dan senam nifas. Checklist merupakan suatu daftar untuk men "cek" yang berisi nama subjek dan beberapa gejala serta identitas lainnya dari sasaran pengamatan. ${ }^{9}$ Checklist dapat bersifat individual dan juga dapat bersifat kelompok. Checklist yang digunakan dalam penelitian ini adalah checklist yang bersifat individual dengan berisi identitas responden dan daftar untuk mengamati ada tidaknya gejala dari sasaran 
penelitian yang telah ditetapkan berdasarkan definisi operasional penelitian. ${ }^{10}$

Penelitian ini dilakukan di RSUD Abd. Aziz Kota Singkawang Tahun 2017 november 2017- desember 2017. Populasi merupakan keseluruhan objek penelitian atau objek yang akan diteliti. ${ }^{10}$ Populasi adalah wilayah generalisasi yang terdiri atas objek (benda) atau subjek (orang) yang mempunyai kulaitas dan karakteristik tertentu yang ditetapkan oleh peneliti untuk diteliti dan kemudian ditarik kesimpulan ${ }^{11}$. Populasi target dalam penelitian ini adalah seluruh ibu nifas di RSUD Dr Abd. Aziz Kota Singkawang sebanyak 30 orang.

Sampel adalah bagian populasi yang akan diteliti oleh peneliti, sampel bisa juga disebut sebagian jumlah dari karakteristik yang dimiliki oleh populasi tersebut. ${ }^{12}$ Sampel adalah objek yang diteliti dan dianggap mewakili seluruh populasi.Sampel diambil dengan metode total sampling. Teknik pengambilan sampel dalam penelitian ini dengan menggunakan total sampling. Total Sampling adalah teknik penentuan sampel dengan mengambil semua anggota populasi sebagai responden.

Analisis univariat bertujuan untuk menjelaskan atau mendeskripsikan karakteristik setiap variabel penelitian. Peringkasan data menggunakan data analisis deskriptif standar SPSS untuk distribusi frekuensi dengan ukuran presentase atau proporsi. Analisis bivariat digunakan untuk melihat hubungan antara variable independentdan variabel dependent dengan menggunakan analisi uji chi square. Melalui uji statistik chi square akan diperoleh nilai $p$, dimana dalam penelitian ini digunakan tingkat kemaknaan sebesar 0,05. Penelitian antara dua variabeldikatakan bermakna jika mempunyai nilai $p<0,05$ yang berarti Ho ditolak dan $\mathrm{Ha}$ diterima dan dikatakan tidak bermakna jika mempunyai nilai $p>0,05$ yang berart Ho diterima dan Ha ditolak.

\section{Hasil}

Berdasarkan Tabel. 1 Distribusi Frekuensi Inisiasi menyusui dini sebanyak 26 responden $(86,7 \%)$ Inisiasi menyusu dini baik dan 4 responden Inisiasi menyusu dini kurang baik (13,3\%). Distribusi Frekuensi Mobilisasi sebanyak 18 responden (60\%) Mobilisasi baik dan 12 responden Mobilisasi kurang baik (40\%). Distribusi Frekuensi Senam nifas sebanyak 21 responden (70\%) Senam nifas baik dan 9 responden Senam nifas kurang baik (30\%). Berdasarkan tabel 2 hasil analisis hubungan inisisasi menyusu dini dengan involusi uteri di RSUD ABD AZIZ Kota Singkawang, Kalbar tahun 2017 diperoleh bahwa ada sebanyak 18 responden $(69,2 \%)$ dari 26 responden mengalami Inisiasi menyusu dini baik dengan involusi uteri normal.

Tabel 1. Gambaran Inisiasi Menyusu Dini (IMD), Mobilisasi Dini, Senam Nifas dan Involusi Uteri antara di RSUD ABD AZIZ KotaSingkawang, Kalbar tahun 2017

\begin{tabular}{lcc}
\hline \multicolumn{1}{c}{ Variabel } & $\begin{array}{c}\text { Jumlah } \\
(\mathbf{n})\end{array}$ & $\begin{array}{c}\text { Presentase } \\
(\mathbf{\%})\end{array}$ \\
\hline Involusi Uteri & & \\
$\quad$ Normal & 20 & 66,7 \\
Tidak Normal & 10 & 33,3 \\
Inisiasi menyusu dini & & \\
$\quad$ Baik & 26 & 86,7 \\
$\quad$ Kurang Baik & 4 & 13,3 \\
Mobilisasi & & \\
$\quad$ Baik & 18 & 60,0 \\
$\quad$ Kurang Baik & 12 & 40,0 \\
Senam nifas & & \\
$\quad$ Baik & 21 & 70,0 \\
$\quad$ Kurang Baik & 9 & 30,0 \\
\hline Sumber: Hasil olah data penelitian tahun 2017
\end{tabular}

Sedangkan diantara responden yang mengalami inisiasi menyusu dini kurang baik ada sebanyak 2 responden (50\%) dari 4 responden Sumber: Hasil olah data penelitian tahun 2017 yang mengalami involusi uteri tidak normal. Hasil uji statistik didapatkan nilai $\mathrm{P}$ value $=0,584$ berarti $\mathrm{p}$ value $>\propto(0,05)$, sehingga dapat disimpulkan tidak ada hubungan inisisasi menyusu dini dengan involusi uteri di RSUD ABD AZIZ Kota Singkawang, Kalbar tahun 2017. Diperoleh nilai OR 2,250 artinya Inisiasi menyusu dini baik berpeluang 2,2 kali mengalami involusi uteri normal dibandingkan yang mengalami Inisiasi menyusu dini kurang baik.

Hasil analisis hubungan mobilisasi dengan involusi uteri di RSUD ABD AZIZ Kota Singkawang, Kalbar tahun 2017 diperoleh bahwa ada sebanyak 15 responden $(83,3 \%)$ dari 18 responden mengalami mobilisasi dengan involusi uteri normal sedangkan diantara responden yang mengalami mobilisasi kurang baik ada sebanyak 7 responden $(58,3 \%)$ dari 12 responden yang mengalami involusi uteri tidak normal. Hasil uji statistik didapatkan nilai $\mathrm{P}$ value $=0,045$ 
Tabel 2. Hubungan Inisiasi Menyusu Dini (IMD), Mobilisasi Dini, dan Senam Nifas dengan Involusi Uteri antara di RSUD ABD AZIZ Kota Singkawang, Kalbar tahun 2017

\begin{tabular}{|c|c|c|c|c|c|c|c|c|}
\hline \multirow{3}{*}{ Variabel } & \multicolumn{4}{|c|}{ Involusi Uteri } & & & \multirow{3}{*}{$\begin{array}{c}P \\
\text { value }\end{array}$} & \multirow{3}{*}{$\begin{array}{c}\text { Or } \\
\text { Lower-Upper) }\end{array}$} \\
\hline & \multicolumn{2}{|c|}{ Normal } & \multicolumn{2}{|c|}{$\begin{array}{c}\text { Tidak } \\
\text { normal }\end{array}$} & \multicolumn{2}{|c|}{ Total } & & \\
\hline & $\mathbf{N}$ & $\%$ & $\mathbf{N}$ & $\%$ & $\mathbf{N}$ & $\%$ & & \\
\hline \multicolumn{9}{|l|}{$\begin{array}{l}\text { Inisisasi } \\
\text { Menyusu Dini }\end{array}$} \\
\hline Baik & 18 & 69,2 & 8 & 30,8 & 26 & 100 & \multirow{2}{*}{0.584} & \multirow{2}{*}{$\begin{array}{c}2,250 \\
(0,267-18,925)\end{array}$} \\
\hline $\begin{array}{l}\text { Kurang baik } \\
\text { Mobilisasi }\end{array}$ & 2 & 50 & 2 & 50 & 4 & 100 & & \\
\hline Baik & 15 & 83,3 & 3 & 16,7 & 18 & 100 & \multirow{2}{*}{0.045} & \multirow{2}{*}{$\begin{array}{c}7,000 \\
(1,293-37,909)\end{array}$} \\
\hline $\begin{array}{l}\text { Kurang baik } \\
\text { Senam nifas }\end{array}$ & 5 & 41,7 & 7 & 58,3 & 12 & 100 & & \\
\hline Baik & 17 & 81 & 4 & 19 & 21 & 100 & \multirow{2}{*}{0.030} & \multirow{2}{*}{$\begin{array}{c}8,500 \\
(1,458-49,539)\end{array}$} \\
\hline Kurang baik & 3 & 33,3 & 6 & 66,7 & 9 & 100 & & \\
\hline
\end{tabular}

berarti $\mathrm{p}$ value $<\propto(0,05)$, sehingga dapat disimpulkan ada hubungan mobilisasi dengan involusi uteri di RSUD ABD AZIZ Kota Singkawang, Kalbar tahun 2017.

Diperoleh nilai OR 7,000 artinya mobilisasi kurang baik berpeluang 7 kali mengalami involusi uteri tidak normal dibandingkan yang mengalami mobilisasi baik. (81\%) dari 21 responden mengalami senam nifas dengan involusi uteri normal sedangkan diantara responden yang mengalami senam nifas kurang baik ada sebanyak 6 responden $(66,7 \%)$ dari 9 responden yang mengalami involusi uteri tidak normal.

Hasil uji statistik didapatkan nilai $\mathrm{P}$ value $=0,030$ berarti $\mathrm{p}$ value $<\propto(0,05)$, sehingga dapat disimpulkan ada hubungan senam nifas dengan involusi uteri di RSUD ABD AZIZ Kota Singkawang, Kalbar tahun 2017. Diperoleh nilai OR 8,500 artinya senam nifas kurang baik berpeluang 8,5 kali mengalami involusi uteri tidak normal dibandingkan yang mengalami senam nifas baik.

\section{Pembahasan}

Hubungan Inisisasi Menyusu Dini Dengan Involusi Uteri Di RSUD ABD AZIZ Kota Singkawang, Kalbar Tahun 2017

Hasil analisis hubungan inisisasi menyusu dini dengan involusi uteri di RSUD
ABD AZIZ Kota Singkawang, Kalbar tahun 2017 diperoleh bahwa ada sebanyak 18 responden $(69,2 \%)$ dari 26 responden mengalami Inisiasi menyusu dini baik dengan involusi uteri normal sedangkan diantara responden yang mengalami inisiasi menyusu dini kurang baik ada sebanyak 2 responden $(50 \%)$ dari 4 responden yang mengalami involusi uteri tidak normal. Hasil uji statistik didapatkan nilai $\mathrm{P}$ value $=0,584$ berarti $\mathrm{p}$ value $>\propto(0,05)$, sehingga dapat disimpulkan tidak ada hubungan inisisasi menyusu dini dengan involusi uteri di RSUD ABD AZIZ Kota Singkawang, Kalbar tahun 2017. Diperoleh nilai OR 2,250 artinya Inisiasi menyusu dini baik berpeluang 2,2 kali mengalami involusi uteri normal dibandingkan yang mengalami Inisiasi menyusu dini kurang baik.

Sejalan dengan penelitian Martina adalah mengetahui adanya hubungan antara inisiasi menyusu dini dengan involusi uteri. Uji hipotesis penelitian ini menggunakan uji statistik dari Wilk's Lambda. Sampel dalam penelitian ini sebanyak 30 orang ibu pospartum. Hasil penelitian yang didapatkan adalah tidak terdapat hubungan antara inisiasi menyusu dini dengan involusi uteri. ${ }^{13}$

Inisiasi menyusu dini (IMD) merupakan salah satu faktor yang mempengaruhi perubahan uterus pada ibu postpartum. Inisiasi menyusu dini atau permulaan menyusu dini adalah bayi mulai menyusu sendiri satu jam setelah lahir. Pengisapan puting payudara oleh 
bayi pada awal masa nifas memperkuat stimulasi pengeluaran oksitosin yang bermanfaat untuk merangsang kontraksi uterus pada ibu setelah melahirkan atau pada masa nifas.

Menurut asumsi peneliti bahwa dari hasil penelitian bahwa mayoritas ibu melakukan IMD pasca melahirkan namun pada kecepatan involusi uteri, IMD tidak ada hubungannya involusi uteri normal bukan karena melakukan IMD atau sebaliknya.

\section{Hubungan Mobilisasi Dengan Involusi Uteri Di RSUD ABD AZIZ Kota Singkawang, Kalbar Tahun 2017}

Hasil analisis hubungan mobilisasi dengan involusi uteri di RSUD ABD AZIZ Kota Singkawang, Kalbar tahun 2017 diperoleh bahwa ada sebanyak 15 responden $(83,3 \%)$ dari 18 responden mengalami mobilisasi dengan involusi uteri normal sedangkan diantara responden yang mengalami mobilisasi kurang baik ada sebanyak 7 responden $(58,3 \%)$ dari 12 responden yang mengalami involusi uteri tidak normal. Hasil uji statistik didapatkan nilai $\mathrm{P}$ value $=0,045$ berarti $\mathrm{p}$ value $<\propto(0,05)$, sehingga dapat disimpulkan ada hubungan mobilisasi dengan involusi uteri di RSUD ABD AZIZ Kota Singkawang, Kalbar tahun 2017. Diperoleh nilai OR 7,000 artinya mobilisasi kurang baik berpeluang 7 kali mengalami involusi uteri tidak normal dibandingkan yang mengalami mobilisasi baik. Sejalan dengan penelitian Oktaviviriani Penelitian dilakukan untuk mengetahui hubungan mobilisasi dini dengan involusi uteri pada ibu post sc di RSI Jemursari Surabaya. Besar sample sebesar 23 responden diambil dengan tekhnik simple random sampling. Analisis data menggunakan uji Chi- Square dengan tingkat kemaknaan $\alpha: 0,05$. Hasil penelitian menunjukkan sebagian besar $(65,2 \%)$ responden kurang melakukan mobilisasi dini, sebagian besar $(73,9 \%)$ mengalami involusi uteri kurang baik. Hasil uji statistik didapat 0,009 , sehingga $\rho<\alpha$ maka H0 ditolak yang artinya ada hubungan mobilisasi dini dengan involusi uteri pada ibu post SC di RSI Jemursari Surabaya. Simpulan bahwa ada hubungan mobilisasi dini dengan involusi uteri pada ibu post SC. Saran yang diberikan untuk tenaga kesehatan, hendaknya bidan memfasilitasi untuk melakukan mobilisasi dini dengan mengajarkan, dan mendampingi ibu melakukan mobilisasi secara bertahap. ${ }^{14}$

Mobilisasi dini adalah (ambulasi dini / early ambulation) dapat mengurangi bendungan lochea dalam rahim, meningkatkan perdarahan sekitar alat kelamin, mempercepat pengembalian alat reproduksi ke keadaan semula. Mobilisasi dini sangat penting dalam mencegah trombofeblitis. Setelah persalinan normal jika gerakan nya tidak terhalang oleh pemasangan infus dan tanda-tanda vitalnya juga normal, biasanya juga ibu untuk mandi dan pergi ke kamar mandi dengan dibantu oleh salah satu keluarga atau sendiri pada 1 atau 2 jam setelah persalinan.

Menurut asumsi peneliti merupakan suatu gerakan yang dilakukan bertujuan untuk merubah posisi semula ibu dari berbaring , miring-miring, duduk sampai berdiri sendiri setelah beberapa jam melahirkan. Tujuan memperlancar pengeluaran lochea (sisa darah nifas) mempercepat involusi, melancarkan fungsi organ gastrointestinal dan organ perkemihan, memperlancar peredaran sirkulasi darah.

\section{Hubungan Senam nifas Dengan Involusi Uteri Di RSUD ABD AZIZ Kota Singkawang, Kalbar Tahun 2017}

Hasil analisis hubungan senam nifas dengan involusi uteri di RSUD ABD AZIZ Kota Singkawang, Kalbar tahun 2017 diperoleh bahwa ada sebanyak 17 responden (81\%) dari 21 responden mengalami senam nifas dengan involusi uteri normal sedangkan diantara responden yang mengalami senam nifas kurang baik ada sebanyak 6 responden $(66,7 \%)$ dari 9 responden yang mengalami involusi uteri tidak normal. Hasil uji statistik didapatkan nilai $\mathrm{P}$ value $=0,030$ berarti $\mathrm{p}$ value $<\propto(0,05)$, sehingga dapat disimpulkan ada hubungan senam nifas dengan involusi uteri di RSUD ABD AZIZ Kota Singkawang, Kalbar tahun 2017. Diperoleh nilai OR 8,500 artinya senam nifas kurang baik berpeluang 8,5 kali mengalami involusi uteri tidak normal dibandingkan yang mengalami senam nifas baik.

Sejalan dengan penelitian Kurniati berjudul hubungan senam nifas dengan involutio uterus di Polindes Alamanda Desa Pohjejer Kecamatan Gondang Kabupaten Mojokerto. Hasil penelitian terdapat 21 responden yang melakukan senam nifas tidak tepat, 16 (76,2\%) diantaranya mengalami involusi uterus yang 
tidak normal. Sedangkan 11 responden yang melakukan senam nifas dengan tepat, 10 (90,9\%) diantaranya mengalami involusi uterus yang normal. Setelah dilakukan uji statistik dengan Chi-Square dengan menggunakan SPSS mendapatkan hasil $\rho$ $=0,000<0,05$ yang artinya ada hubungan antara senam nifas dengan involutio uterus.

Senam nifas merupakan salah satu cara untuk mengurangi berbagai masalah atau gangguan fisiologis maupun psikologis yang terjadi pada ibu postpartum. Hal ini karena senam nifas merupakan cara untuk mobilisasi dini yang sangat dianjurkan untuk ibu postpartum. Manfaat dari latihan ini hubungannya dengan pemulihan fisik pada ibu yang melakukannya yaitu mencegah diastasis rektus abdominis dan mengencangkan otot abdomen, sehingga angka prevalensi kejadian diastasis rectus abdominis dapat diturunkan. ${ }^{15}$

Menurut asumsi Involusi uterus adalah perubahan yang merupakan proses kembalinya alat kandungan atau uterus dan jalan lahir setelah bayi lahir hingga mencapai keadaan sebelum hamil yang dipengaruhi oleh mobilisasi dan senam masa nifas. Saat masa nifas para ibu di haruskan untuk melakukan senam nifas atau senam setelah melahirkan. Senam ini dilakukan sejak hari pertama setelah melahirkan hingga hari kesepuluh. Dalam pelaksanannya, harus dilakukan secara bertahap, sistematis, dan kontinyu. Senam nifas penting sekali di lakukan oleh ibu yang telah melahirkan untuk mengembalikan kebugaran tubuh pasca persalinan.

\section{Kesimpulan}

Berdasarkan hasil penelitian yang penulis lakukan tentang Hubungan Inisiasi Menyusu Dini (IMD), Mobilisasi Dini, dan Senam Nifas dengan Involusi Uteri di RSUD ABD AZIZ Kota Singkawang, Kalimantan Barat Tahun 2017. Distribusi Frekuensi Involusi Uteri Di RSUD ABD AZIZ Kota Singkawang, Kalimantan Barat Tahun 2017 sebanyak 20 responden $(66,7 \%)$ involusi normal, 26 responden $(86,7 \%)$ Inisiasi menyusui dini baik, 18 responden (60\%) Mobilisasi baik, 21 responden (70\%) Senam nifas baik. Hasil uji statistik didapatkan nilai $\mathrm{P}$ value $=0,584$ berarti $\mathrm{p}$ value $>\propto(0,05)$, sehingga dapat disimpulkan tidak ada hubungan inisisasi menyusu dini dengan involusi uteri di RSUD ABD AZIZ Kota Singkawang, Kalimantan Barat tahun 2017.
Hasil uji statistik didapatkan nilai $\mathrm{P}$ value $=$ 0,045 berarti $p$ value $<\propto(0,05)$, sehingga dapat disimpulkan ada hubungan mobilisasi dengan involusi uteri di RSUD ABD AZIZ Kota Singkawang, Kalimantan Barat tahun 2017. Hasil uji statistik didapatkan nilai $P$ value $=0,030$ berarti $\mathrm{p}$ value $<\propto(0,05)$, sehingga dapat disimpulkan ada hubungan senam nifas dengan involusi uteri di RSUD ABD AZIZ Kota Singkawang, Kalimantan Barat tahun 2017.

\section{Saran}

Kepada Tenaga Kesehatan selaku Penyedia Pelayanan Kesehatan terutama Bidan memberikan edukasi kepada ibu postpartum tentang bagaimana mencegah terjadinya involusi uteri. Bagi Ibu Postpartum Mencari informasi tentang cara mempercepat pemulihan kondisi rahim dari hamil ke kondisi seperti tidak hamil. Bagi penelitian selanjutnya untuk dapat dikembangkan dan diteliti secara mendalam dengan pendekatan kualitatif dan wawancara secara mendalam.

\section{Daftar Pustaka}

1. Risnen. Buku Ajar Asuhan Kebidanan Nifas dan Menyusui. Jakarta. Trans Info Media (TIM); 2016.

2. Saleha S. Asuhan Kebidanan Pada Masa Nifas. Jakarta: Salemba Medika; 2009.

3. Anggraini Y. Asuhan kebidanan Masa Nifas. Yogyakarta : Pustaka Rihama; 2010.

4. Wiknjosastro. Ilmu kandungan. Jakarta: Yayasan Bina Pustaka Sarwono Prawirohadjo; 2008.

5. Maryunani A. Inisiasi Menyusu Dini, ASI Eksklusif Dan Manajemen Laktasi. Jakarta : CV. Trans Info Media; 2012.

6. Marmi. Asuhan Kebidanan Pada Masa Nifas "puerperium care". Yogyakarta: Pustaka Pelajar; 2012.

7. Widianti dan Proverawati. Senam Kesehatan, Yogyakarta: Nuha Medika; 2010.

8. Notoatmodjo S. Metodologi Penelitian Kesehatan. Ed Rev. Jakarta:Rineka Cipta; 2010.

9. Notoatmodjo S. Metodologi Penelitian Kesehatan. Jakarta: Rineka Cipta; 2012.

10. Hidayat AA. Metode Penelitian Kesehatan. Surabaya: Health Books Publishing; 2010

11. Suharsimi A. Prosedur Penelitian. Jakarta: Rineka Cipta; 2010.

12. Sugiyono. Metode Penelitian Kuantitatif Kualitatif dan R\&D Bandung: Alfabeta; 2014. 
13. Martina BO. Hubungan Antara Inisiasi Menyusui Dini Dengan Involusi Uteri Pada Ibu Postpartum. Jurnal Kesehatan; 2014.

14. Oktaviviriani D. Hubungan Mobilisasi Dini Dengan Involusi Uteri Pada Ibu Post Sc Di Rsi Jemur Sari Surabaya. [Undergraduate Thesis]. Universitas Nahdatul Ulama Surabaya; 2010.
15. Ambarwati W. Asuhan Kebidanan Nifas Yogyakarta: Nuha Medika; 2010. 